\title{
Is Big History a Movement Culture?
}

\author{
William Katerberg \\ History Department \\ Calvin College, Michigan
}

\begin{abstract}
This essay analyzes Big History as a movement, one that has been evolving from individuals and small groups of people working independently to a scholarly community and a set of institutions no longer dependent on founding individuals. The essay uses theoretical models to do so, notably movement cultures in politics and Thomas Kuhn's idea of paradigm shifts in science. It compares Big History to movement building in the early modern era, notably the "Republic of Letters" (i.e., Enlightenment and Scientific Revolution) and religious revivals. Finally, it compares Big History to related genres that explore the past on a large scale. The essay's goals are both empirical and reflexive, to help practitioners of Big History understand what their field is and, in doing so, consider what it should be.
\end{abstract}

The conversion narrative is an autobiographical genre familiar to scholars of religious history. The genre is characterized by stories of awakening, enlightenment, and wonder, of being lost and then now found, and setting on a new path, often with a mission. The story is a form of witness to others, in solidarity with others who have seen the light, and as inspiration for those who have not yet seen it. The road to awakening can be long and gradual or come in an instant, in a road to Damascus encounter. Such stories are essential to the coherence and growth of movements. Big Historians often tell loosely similar kinds of stories of their intellectual awakening in discovering Big History, setting them on new scholarly or teaching paths or new forms of activism. The IBHA Newsletter, now Origins, has regularly included such narratives. ${ }^{1}$

My own first encounter with Big History was through David Christian's book, Maps of Time, which I stumbled across in an Amazon search for

1 The idea for this essay goes back to hearing autobiography stories in presentations and information conversations at IBHA conferences in Grand Rapids in 2012 and at Dominican University in 2014 and reading autobiographical stories like this in the newsletter and Origins. I gave it as a paper at the IBHA conference in Amsterdam in 2016. another book related to world history, the algorithms of Amazon rather than an itinerant Big History evangelist telling me that I might be interested in the book. ${ }^{2}$ I was. Maps of Time helped me to conceptualize with a new clarity my own loosely held ideas about how human history related to evolutionary history and how my own discipline of history might relate to disciplines that study the deep past. When the International Big History Association came to Grand Rapids in 2012 for its inaugural conference, I decided to explore Big History as a discipline, a community, and a growing set of institutions. I also started incorporating elements of Big History into my classes.

This essay explores whether the field of Big History, as a field of study, is a movement culture. The essay is meant to be both impartial, in exploring what Big History is, and reflexive, in spurring practitioners to reflect on what they are doing as

2 Maps of Time: An Introduction to Big History (Berkeley: University of California Press, 2004). There are itinerant Big History evangelists. An example is Michael Dowd, who has participated at Big History conferences. His website, The Great Story," describes him as "a Big History evangelist, evolutionary theologian, and bestselling author," http:// thegreatstory.org/god-in-big-history.html (accessed 22 November 2017). 
Big Historians and why. By movement culture, I mean evolution from individuals and small groups of people working independently or in loose conversation to a self-conscious community and a set of institutions no longer so dependent on founding individuals. The essay also uses Thomas Kuhn's idea of paradigm shifts and makes comparisons to political movements and early modern networks of letter writers. It explores how Big Historians tell stories, of humanity's place in the universe and of their discovery of Big History. Finally, it compares Big History to related genres that explore the past on a large scale. Big History has matured enough as a community and set of institutions where a diversity of goals and vision in the movement are leading to factions and even conflict, tensions familiar to intellectual movements that seek a secure, respected place in the academy and aspire to influence more widely in society.

\section{Movement Cultures}

Thomas Kuhn's "paradigm shift" explanation for scientific revolutions is best known for the epistemological questions it raises. "Kuhn argued that each scientific field is organized around an overarching, or paradigmatic, theory. In normal, everyday science the social networks and community experiences of scientists in laboratories and professional associations help reinforce the dominant paradigm. Sealed off in their enclaves, scientists routinely try to explain away any anomalies that their research might turn up. Only when forced by mounting evidence to confront these anomalies will some scientists ... make a sudden mental shift which permits them to break with normal science." ${ }^{\prime 3}$ In

3 Joyce Appleby, Lynn Hunt, and Margaret Jacob, Telling the Truth About History (New York: Norton, 1994), 164. For a short general introduction to Kuhn's thought, see Alexander Bird, "Thomas Kuhn", The Stanford Encyclopedia of Philosophy (Fall 2013 Edition), Edward N. Zalta (ed.), http://plato.stanford.edu/archives/fall2013/entries/thomaskuhn/. For an overview of recent discussion in the history and philosophy of science, see John Zammito, A Nice Derangement of Epistemes: Post-positivism in the Study of Science from Quine to Latour (Chicago: University of these revolutionary moments new models of science, such as Darwin's theory of natural selection, can win adherents. Science does not evolve as a result of steady accumulation of empirical data and ongoing refining of theoretical models, Kuhn argued. Normal science resists fundamental change, whether in methodology or metaphysics, and the institutions of science are designed to replicate existing approaches and hold off outlying methods and marginal theoretical perspectives - as was the case with natural selection and the big bang. As this summary suggests, part of a scientific revolution is conceptual, a new way of thinking.

Equally important, and more important for this paper, is the battle Kuhn described over institutions and the creation of new movements and institutions in revolutionary moments in science, as defenders of prevailing normal science battle with advocates of revolution science, and sometimes revolutionary science becomes the new normal. Scholarship in the history of science confirms this institutional component. For example, debates over natural selection in the nineteenth century intersected with conflict between gentlemen amateur scientists and scientists who professionalized their work in new research institutions and universities. The revolution was not only conceptual-older creation accounts versus evolutionary ones, or Lamarckian vs Darwinian forms of evolutionary theory-but over who scientists were, how they should be trained, and how and where they did their work. ${ }^{4}$

What sort of paradigm shift does Big History

Chicago, 2004). From Kuhn, of course, see The Structure of Scientific Revolutions: 50th Anniversary Edition (Chicago: University of Chicago, 2012).

4 A useful, reader friendly overview of institutions of knowledge, including a chapter on the modern university and one on the laboratory, is Ian McNeely, with Lisa Wolverton, Reinventing Knowledge: From Alexandria to the Internet (New York: Norton, 2008). A useful biographical case study is Adrian Desmond, Huxley: From Devil's Disciple to Evolution's High Priest (New York: Basic Books, 1997). For the general history, see Peter J. Bowler and John Pickstone, eds., The Cambridge History of Science, Volume 6, Modern Life and Earth Sciences (Cambridge, UK: University of Cambridge Press, 2009). 
represent, then? It is not a revolution in a specific scientific discipline, as described by Kuhn. It is a narrative and analytical synthesis of the work of today's "normal science" in disciplines across many fields, from the natural sciences to the social sciences and humanities. Big history's synthetic impulse is counter-cultural in an intellectual world dominated by disciplinary specialization and a social culture characterized by fracture. ${ }^{5}$ But Kuhn's core idea is still valuable here. What is the appeal of big synthesis today, for some people, and why do disciplinary silos seem unsatisfying to them? Big History is an intellectual and cultural insurgency in its synthetic ambition and in seeking to influence not only academia, but also public discussion of issues related to science and society and elementary, middle, and high school curricula. The next section of the paper will explore these issues in more detail. This rest of this section briefly focuses on practical side of Kuhn's paradigm shift model: how new movements evolve institutionally.

One helpful model for thinking about such evolution is Lawrence Goodwyn's notion of a movement culture. A movement culture is not just an alternative way of thinking or living, different from the mainstream; it is oppositional. That is, it seeks to transform a received culture. Goodwyn pointed to "the sequential process of democratic movement-building, in the creation of new institutions ("movement forming"), new means to attract masses of people ("movement recruiting"), successful cultural formation ("movement educating"), and influence on society ("movement politicized"). ${ }^{6}$ The first three of these apply readily

5 See Daniel T. Rodger's recent study, Age of Fracture (Cambridge, MA: Harvard University Press, 2011).

6 Lawrence Goodwyn, The Populist Moment (New York: Oxford University Press, 1978), xviii. Goodwyn used the concept to explain the rise of the Populists, an agrarian political movement in the American South and West in the late-nineteenth century. The concept also has been used to examine labor movements in that era. See William S. Solomon and Robert W. McChesney, eds., Ruthless Criticism: New Perspectives in U.S. Communication to Big History - in the IBHA itself, the Big History project, Chronozoom, and curriculum for schools, books for children, and popular documentary films. ${ }^{7}$ Big History is not a political movement. Nonetheless, working toward a sustainable future is a motivation for many of its proponents, as advocates who have learned from Big History to envision humanity's evolving place on our planet in new ways, and as responsible citizens who have become determined to care for it. ${ }^{8}$

Two other historical analogies strike me as relevant, both from the early modern era. People rightly look to the print revolution to explain the impact of the Reformation, Scientific Revolution, evangelical revivals, and Enlightenment. Historians have shown that letters played a major role as well. Civil society first emerged in what historians sometimes refer to as the "Republic of Letters," as intellectuals spread word of new books and ideas in letters meant to be copied and to be read to groups in homes, salons, and scientific societies. Scholars have even mapped some these connections in digital

History (Minneapolis: University of Minnesota Press, 1993), particularly the chapters on working class politics and newspapers. Big Historians articulate a vision of science common in that same era, in which science offered a "comprehensive worldview," one that could replace "religious authorities" as the ground for ethical living and democratic citizenship and foster a Progressive future. See Andrew Jewett, Science, Democracy, and the American University: From the Civil War to the Cold War (Cambridge, UK: Cambridge University Press, 2012), 2.

7 Chronozoom's status in the future is uncertain, but the site remains accessible. http://www.chronozoom.com/ (accessed 22 November 2017). For the Big History Project, go to https://www.bighistoryproject.com/home (accessed 22 November 2017). The International Big History Association Website is https://bighistory.org/ (accessed 22 November 2017).

8 See, for example, David Gabbard, "Big History's Greatest Lesson? How to Find Humility in Our Commonality," Origins IV:4 (2014), 7-8. From the related field of ecological economics, see Robert Costanza, Lisa K. Graumlich, and Will Steffen, eds., Sustainability or Collapse: An Integrated History and Future of People on Earth, Dahlem Workshops Report (Cambridge, MA: MIT Press, 2007). 
history projects. ${ }^{9}$ Likewise, in the Great Awakenings of the eighteenth century, Protestant revivalists from Europe to the British Isles and North America spread word of religious renewal, reading each other's letters, publishing news of new awakenings, and spreading new theologies. Today the internet makes the creation of literal and virtual communities easier, locally and globally. ${ }^{10}$ Websites such as Metanexus, The Great Story, Center for the Story of the Universe, and the Big History Project come to mind, as do groups on Facebook and videos on YouTube, Vimeo, and the TED website. As with the Republic of Letters and Great Awakening, Big History's networks include scholars, popularizers, and patrons reaching out to diverse audiences, from intellectuals, to children, to religious seekers. ${ }^{11}$

As movement cultures grow, they tend to both formalize and diversify, sometimes maintaining a "big tent" unity, albeit with tensions, sometimes falling into factions and boundary setting, institutionally and intellectually. ${ }^{12}$ Such divisions

9 For short introductions to the Republic of Letters, see Appleby et al, Telling the Truth About History, chapter 1; and McNeely, Reinventing Knowledge, chapter 4. See a project at Stanford University, "Mapping the Republic of Letters." http://republicofletters.stanford.edu/index.html (accessed 7 May 2016); the case study on Benjamin Franklin shows transatlantic connections: http://republicofletters.stanford.

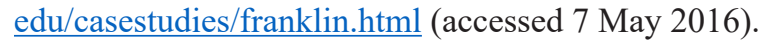

10 On how promoters of religious revivals in the same era created a transatlantic movement, see Susan O'Brien, “A Transatlantic Community of Saints: The Great Awakening and the First Evangelical Network, 1735-1755," American Historical Review 91:4 (October 1986), 811-832; Jennifer Snead, "Print, Predestination, and the Public Square: Transatlantic Evangelical Periodicals, 140-1745," EAL 45 (2010), 93-118; and, Frank Lambert, Inventing the "Great Awakening" (Princeton, NJ: Princeton University Press, 2001).

11 On Big History's patron, see Andrew Ross Sorkin, "So Bill Gates Has This Idea for a History Class," New York Times Magazine, The Education Issue, 5 September 2014; http:// www.nytimes.com/2014/09/07/magazine/so-bill-gates-hasthis-idea-for-a-history-class.html (accessed 14 May 2016).

12 For an overview of scholarship on boundaries and the social sciences, see "Michèle Lamont and Virág Molnár, "The Study of Boundaries in the Social Sciences," Annual Review of Sociology 28 (2002) 167-95. often involve negotiating the boundary between elite and popular expressions of the movement. They also stem from significant intellectual and cultural differences or distinct goals, particularly tensions between strategic compromises with the received culture and oppositional radicalism.

\section{Big History as a Movement Culture}

The received culture addressed by Big History is a specialized, sub-divided, siloed, even "fractured" intellectual culture, characteristic of both academia and society at large today. The revolution promoted by Big History is a new way to integrate knowledge, a "great story" based on science that not only provides a scholarly synthesis across the disciplines, but also a "modern mythology" that can help people to understand their world and their place in the universe and motivate them to address global problems.

The mythic element in Big History is evident in the way individuals make it part of their own stories and vocations. "I had spent my entire career as a student and a teacher thinking of knowledge as needing to be carved up into bite sized, easily digestible and deliverable pieces," explained Tracy Sullivan in the IBHA Newsletter in 2012. "Big History has shown me the immense power of the interaction of knowledge across the largest scales and the broadest array of disciplines. Paradoxically, by defining this landscape of understanding in the largest possible frame Big History has led to me no longer feel overwhelmed and lost." This is what myth-histories do-provide narrative order to the fragmented pieces of the past, present, and future (whether empiricallybased or fictional). "I am now inspired and excited to engage with a narrative and theoretical structure that is simple enough to guide my inquiry yet complex enough to allow for continued investigation, learning and discovery," Sullivan went on to say. "The beauty of this subtle balance between 'simplicity' and 'complexity' is that Big History becomes accessible to those at all levels of the educational spectrum from primary school through to academic 
researchers." ${ }^{13}$ Sullivan's short autobiographical essay effectively summarized how Big History is both a narrative synthesis, with mythic resonances, and an interdisciplinary scholarly field, perhaps best compared to "area studies" programs, its "area" encompassing the entire planet and universe.

Sullivan also explained how the institutions associated with Big History connected her personal transformation to a larger community. "During the IBHA conference I was struck by how often the words 'awe' and 'wonder' were used. Not about subject matter alone, but how Big History has a transformative power on the way people experience and understand the world and environments around them," Sullivan said. She wants this for her students. "Having a sense of being part of something far greater than oneself, and an understanding of what an astoundingly beautiful, fragile and volatile 'something' that is, changes the way we perceive ourselves and our environments. It has certainly done this for me. If I tend to sound like a Big History evangelist I am proud to say that I am." ${ }^{14}$ Not all Big Historians use such religious language, though it is noteworthy how often religious metaphors and allusions crop up in Big History conversations, even among avowedly atheist or agnostic scholars. The key point here is how consistently-in panels and informal conversations at IBHA conferences, in essays in the IBHA newsletter or Origins, or other online venues - autobiography is part of participating in Big History. ${ }^{15}$ I generally do not observe this pattern at other scholarly associations and meetings in which I participate regularly. Exceptions in my experience include panel sessions that discuss the

13 As the paragraph suggests, I use the term mythic here not as a measure of good or bad history (or science), but a story told to shape an identity, whether of a person or a group. Tracy Sullivan, "Teaching Big History," International Big History Association Member's Newsletter II:8 (November 2012), 6-7. 14 Sullivan, "Teaching Big History," 7.

15 For further examples, see Kenneth Gilbert, "Across the Shores of Big History: Footprints in the Sands of Time," is a good example; see International Big History Association Member's Newsletter II:8 (November 2012), 1-6; and Gabbard, "Big History's Greatest Lesson?" intersection of personal religious commitments and studying religious history. Autobiographical reflection also is common in the context of African American studies, women's studies, and LGBTQ+ scholarship. ${ }^{16}$ The common denominator in these examples seems to be (1) new, still marginal fields of scholarship securing their place in academia; and (2) fields of study with close ties to social and political movements. In these cases, we can see how the personal is political, to use a familiar feminist trope, and how the intellectual is personal. We also can see negotiation of boundaries, as fields of study become more mainstream.

Boundary conversations took place at the IBHA conference in California in 2014 and more have followed in Origins since then. Four scholars published a letter entitled "Is the IBHA at a Crossroads?" They addressed concerns about speakers at some panels "using Big History as a platform to promote personal 'spiritual' agendas," where the lines between "science" and "interpretation," and "facts" and attributed "meaning," were transgressed. They also noted the "screening of Journey of the Universe," a

16 In general, in historical scholarship, see chapters 13-16 in Peter Novick, That Noble Dream: The 'Objectivity Question' and the American Historical Profession (New York: Cambridge University Press, 1988)). A useful study of issues related to gender and sexuality is Jo Reger, Daniel J. Meyers, and Rachel L. Einwohner, eds., Identity Work in Social Movements (Identity Work in Social Movements (Minneapolis: University of Minnesota Press, 2008). On African American history, see V.P. Franklin, "The Power to Define: African American Scholars, Activism, and Social Change, 1916-2015," The Journal of African American History 100:1 (2015), 1-25. Note also Charles Tilly, in "Political Identities in Changing Polities," Social Research 70:2 (2003), 605-620; and Stories, Identities, and Political Change (Lanham, MD: Rowan and Littlefield, 2002). On personal history and religious history, see essays by Anthea Butler, Richard Bushman, Brad Gregory, Mark Noll, Paul Kerry, and Donald Yerxa, all in Fides et Historia, 43:2 (2011), 1-41. Note also Nick Salvatore, ed., Faith and the Historian: Catholic Perspectives (Urbana: University of Illinois Press, 2007); and Donald J. D'Elia and Patrick Foley, eds., The Catholic as Historian (Naples, Fla.: Sapientia Press of Ave Maria University, 2006) 
documentary film by Brian Swimme: "For some, it expressed the anthropic notion that the universe has a larger purpose; and tells a 'story.' For others, the narrative seemed to express a 'naive, romantic view' with a 'spiritual' interpretation." The discussion that followed revealed a "split" between "scientists" and "spiritualists." 17 One might quibble about the details of this account. Scientists can also be spiritualists, after all. And the line between "facts" and "interpretation" is blurry in science (as in other fields), according to the consensus of scholars in the history, sociology, and philosophy of science. ${ }^{18}$ But the letter writers were quite right in what is at stake. Should the IBHA pursue an inclusive or exclusive path? "An inclusive approach would offer a wide variety of insights and the creativity necessary for a young organization and discipline to grow," they noted. "The downside, however, is that the lack of scholarly rigor is likely to dissuade scientific researchers from participating and would undermine the credibility of the association and the discipline. Exclusion, on the other hand, implies the risk of creating an isolated, homogenous, and a somewhat detached research environment that may suffer from confirmation bias and inbred development." The authors suggested that the IBHA offer two tracks, one with a rigorous peer-reviewed process for academic papers and one for spiritual "interpretation." 19 This dual approach leaves room for a big tent, though it clearly sees the core of Big History as scientific and could be viewed as trying to quarantine the spiritual track so that those uninterested in it can easily avoid it.

17 Laura Rahm, Steve Sisney, Gus Lyn-Piluso, and J. Daniel May, "Is the IBHA at a Crossroads?" Origins IV:10 (2014), 20-21.

18 I explored this issue in "Myth, Meaning and Scientific Method in Big History," Origins V:12 (December 2015), 3-12.

19 Rahm, Sisney, Lyn-Piluso, and May, "Is the IBHA at a Crossroads?" 20-21. Fred Spier implicitly affirmed these concerns, in a response, noting that this issue has been discussed since the 2012 IBHA conference; see Spier, "Reply to: Is the IBHA at a Crossroads?" Origins IV:10 (2014), 22 The process of proposing academic papers/panels for the 2016 conference followed the suggestions of the letter writers, at least loosely.
Imogene Drummond pushed in the opposite direction in "A Visionary, Transformative, Diverse IBHA," published in the same issue. She opposed the creation of two Big History organizations and urged the IBHA to expand its "identity or mission statement to include three core concepts: Macro, Transformative, Visionary." Macro approaches to Big History, in her conception, are about cooperative cultural thinking that will allow humanity to flourish. Transformative approaches focus on education and popularization outside scholarly circles, in school curricula and the arts. The Visionary emphasis is about new concepts and ideas to link knowledge across disciplines. All these are equally and rightfully part of Big History, she argues. ${ }^{20}$

The "scientific," metaphysical, and moral cannot easily be separated, the letter writers and Drummond seem to agree. The question is how to have productive conversations about them. Big History does not require a monolithic worldview and much of its work is empirical. ${ }^{21}$ Nevertheless, all Big History work involves non-empirical worldview assumptions, including the scholarship of Big Historian scholars who work in the sciences. Philosophical, aesthetic, and even theological conceptions are embedded in core big history concepts (e.g., complexity and emergence). ${ }^{22}$ The "mapping" that Big Historians

20 Imogene Drummond, "A Visionary, Transformative, Diverse IBHA," Origins IV:10 (2014): 23-25. A good example of the kind of work that Drummond proposed is Joseph Voros, "The Past, Present and the Future: A Q\&A with Futurist and Academic Member of the Big History Institute, Macquarie University," Origins 6:4 (2016): 3-6. Voros makes the case for a variety of public policies that will promote the ongoing sustainability of human progress. He also speculates, in the borderland between science and science fiction, about what might lie beyond our planet: "fellowships ... with other intelligences and civilisations," "in futures that may yet come."

21 Fred Spier addressed the question of worldview in "Big History is Not an All-Encompassing World View," Origins VI:2 (2016): 3-5.

22 In "The Meaning of Big History, Philosophically Speaking," Cynthia Stokes Brown describes Big History involving methodological materialism, but not philosophical materialism; see Origins VI:1 (2016): 7-13. She also notes "that hidden between these lines are many layers of 
do is shaped by conceptions that entail "meaning." ${ }^{23}$ There is no neutral empirical base of science on which meaning is imposed. The two shape each other in subtle ways. David Christian has argued that Big History is a scientific version of "universal history," a tradition that in the West that dates back to the ancient Greeks, Romans, Hebrews, and to classical, medieval, and early modern Christians. ${ }^{24}$ Allan Megill, Nasser Zakariya, Ian Hesketh, Peter Harrison, and others have argued that the narrative and science of Big History remain indebted to these deeplyrooted philosophical and theological traditions. ${ }^{25}$ In

philosophical thought" (7).

23 I am here riffing on David Christian's title, "From Mapping to Meaning," in Alan Culpepper and Jan van der Watt, eds., Creation Stories in Dialogue: The Bible, Science, and Folk Traditions (Leiden, Boston and Tokyo: Brill, 2015). My point is not an intellectual "Gotcha!" Rather, it is to point to common ground in the reflections of those who practice Big History and those who analyze it critically as historiographers.

24 "The Return of Universal History," History and Theory, Theme Issue 49 (December 2010), 6-27. For a precursor of sorts, by the longtime dean of world history, William H. McNeill, see "The Changing Shape of World History," History and Theory, 34:2 Theme Issue 34: World Historians and Their Critics (May, 1995), pp. 8-26. Like Christian, McNeill noted the mythic power of world history (coining the term "mythhistory" decades earlier) and its relevance given the crises of the late twentieth century.

25 Megill, "Big History' Old and New: Presuppositions, Limits, Alternatives," Journal of the Philosophy of History 9:2 (2015): 306-326; Nasser Zakariya, "Making Knowledge Whole: Genres of Synthesis and Grammars of Ignorance," Historical Studies in the Natural Sciences 42:5 (November 2012): 432-47; Ian Hesketh, "The Story of Big History," History of the Present, 4:2 (Fall 2014): 171-202; Thomas M. Lessi, "Science and the Sacred Cosmos: The Ideological Rhetoric of Carl Sagan," Quarterly Journal of Speech 71:2 (1985): 175-187; Hesketh, "The Recurrence of the Evolutionary Epic," Journal of the Philosophy of History 9:2 (2015): 196-219. Zakariya, Towards a Final Story: Time, Myth and the Origins of the Universe (PhD dissertation: Harvard University, 2010) and Alex Moddejonge, The Biggest Story Ever Told: On the Historiographic Origins of Big History (MA thesis: California State University San Marcos, 2012) and Peter Harrison, "Sacred History, Evolutionary History, and the Status of Human Beings," a lecture at the University of Queensland, Institute for Advanced Studies in the Humanities, 7 April 2016. The other words, Big History has its own deep history. Such deep roots characterize all academic disciplines. What is unusual about Big History is that these issues are discussed explicitly, rather than left suppressed. Big History's emphasis on synthesis and a singular narrative that "maps" across time from the Big Bang to the present brings such matters to the fore, especially in popular expressions of it. The question is not whether Big Historians and IBHA should avoid talking about boundary issues or include them as an essential component of doing Big History. We have been doing the latter since 2014 at least. The questions are: (1) How to do it and to what end? (2) Will Big History as a field of study and intellectual and cultural movement hold together in the process or will it fragment?

\section{Comparisons}

Some wisdom for how the IBHA and Big Historians should address boundary issues can be found in comparing Big History to related fields of study. The closest of these fields are deep history, evolutionary history, and ecological economics. All of these are multi-disciplinary, like Big History, though all limit their scale to the period since the emergence of early humans. Deep history integrates the study of early humans ("prehistory") and postNeolithic history, areas of work normally done separately, to see how they can illuminate each other-in areas such as family life, community formation, food cultures, religious expression, and communication. Evolutionary history examines the co-evolution of humans (and human societies) and other species. ${ }^{26}$ Ecological economics analyzes

podcasts of the lectures are here (scroll down to April 7):

https://iash.uq.edu.au/node/746 (accessed 8 May 2016).

26 For a review of work in these areas, see Nasser Zakariya,

"Is History Still a Fraud?" Historical Studies in the

Natural Sciences 43.5 (2013): 631-641. In addition to several works of Big History, Zakariya reviews Edmund Russell, Evolutionary History: Uniting History and Biology to Understand Life on Earth (Cambridge: Cambridge University Press, 2011); and, Daniel Lord Smail, On Deep History and the Brain (Berkeley: University of California Press, 2001). Note also Andrew Shyrock and Daniel Lord 
the co-evolution of human political economies and natural ecosystems, with an eye to sustainability. Exploring the histories of ecological collapse and the recovery of civilizations, ecological economics can help us understand and address twenty-first century problems of sustainability. Ecological economics straddles the boundary between academic institutions and think tanks, and this field is much more "applied" in its scholarly goals than Big History. ${ }^{27}$ Compared to Big History, these fields are strictly scholarly and technical. They do not aspire to a scientific universal history, to reshape high school and university curricula, or to serve as a "modern mythology." Because these fields are narrower, they do not have the boundary issues addressed in this essay, around morals, meaning, philosophy, theology, and spirituality. Nor do they have the popular influence that Big History has achieved in recent years. They are not movement cultures seeking wider public influence or to transform elementary, middle, and high school curricula.

In Big History's aspiration to shape school curricula, especially through the Big History Project, a useful comparison is survey courses in Western Civilization and world history in high school, colleges, and universities. In all three cases, an essential goal has been to shape citizens, in the interest of shared identities and the knowledge, values, and thinking skills needed to be thoughtful citizens of their nations and the world. Simplifying, Western Civilization courses emerged in North America in 1920s and 1930s, in the wake of World War I and the crises that led to World War II, as educators asserted the need for students to understand their place not just in their nation but the larger world. That larger world was defined by Western Europe, the presumed "mainstream" of human progress in history. In the 1970s, 1980s, and 1990s, civil rights movements, immigration to North America and Europe from the Global South,

Smail, eds., Deep History: The Architecture of Past and

Present (Berkeley: University of California Press, 2012).

27 For an example of work in this area, see Costanza,

Graumlich, and Steffen, eds., Sustainability or Collapse. and globalization led to world history courses replacing Western Civilization courses. Educators recognized that "the West" was only part of the larger world, not its mainstream, and that migration and globalization were transforming North America and Western Europe. ${ }^{28}$ Big History has done the same in the past decade or so, as issues such nuclear war, global sustainability, and climate change - the "Anthropocene" - indicate that world history needs to be expanded by placing the history of our species in the context of planetary and cosmic history. ${ }^{29}$

In all three cases, boundary issues have been central. How should "scholars" in universities work with "teachers" in middle and high schools? How do ideals of objectivity and studying the past for its own sake fit with "civilizational" goals

28 On these fields, see Gilbert Allardyce, "Toward World History: American Historians and the Coming of the World History Course," Journal of World History 1:1 (spring 1990), 23-77; Lawrence Levine, The Opening of the American Mind (Boston: Beacon, 1996); Gary B. Nash et al, History on Trial: Culture Wars and the Teaching of the Past (New York: Vintage, 2000); Patrick Manning, Navigating World History: Historians Create a Global Past (New York: Palgrave, 2003); Lynn Hunt, Writing History in the Global Era (New York: Norton, 2015); and, Paul Costello, World Historians and Their Goals: Twentieth Century Answers to Modernism (DeKalb, IL: Northern Illinois Press, 1994). See also chapters 3 and 4 of Appleby et al, Telling the Truth About History.

29 The "Anthropocene" is the proposed name for a new geological era, beginning in the late eighteenth century, defined by the impact of humanity and our modern industrial civilization, identifiable in everything from radiation in soils around the globe to mass extinctions of plant and animal species, pollution, etc., all of which will leave a mark in the geological stratum of the planet that geologists can identify. On this question, see Joseph Stromberg, "What is the Anthropocene and Are We in It?" Smithsonian Magazine, January 2013, http://www.smithsonianmag.com/ science-nature/what-is-the-anthropocene-and-are-we-in-it164801414/?no-ist (accessed 5/14/2016). For an essay that makes the case, see Will Steffen et al., "The Anthropocene: conceptual and historical perspectives," Philosophical Transactions of the Royal Society A 369 (2011): 842-67. On the Anthropocene and historiography, see Dipesh Chakrabarty, "The Climate of History: Four Theses," Critical Inquiry 35:2 (Winter 2009): 197-222. The essay has since been published in a variety of venues online. See, for example, http://www.sciy.org/?p=3416 (accessed 4/28/2016). 
of shaping citizens, values, and identities? How to take sophisticated technical scholarship and make its accessible for young readers and popular consumption? How should scholars work with citizens and officials on local and state boards that make decisions about curriculum? National and state standards for U.S. and world history both have been controversial for the past three decades. Ties between the scholarly organizations and teachers grew in the 1920s and 1930s and declined in the post-World War II era. Teachers continue to have a secondary place in major organizations such as the American Historical Association, though the AHA has had more panels on pedagogy in the past decade. Perhaps significantly, the World History Association is most like the IBHA in putting a significant emphasis on pedagogy and making a place for teachers. By taking on a planetary and cosmic scales of history, questions about meaning and worldview are inevitable for Big History, as questions of citizenship and identity have been in national, Western Civilization, and world history curricula. ${ }^{30}$ If the IBHA as an organization considers school curriculum and influence on public life as part of its mandate, then boundary issues of the sort addressed in this essay are an essential part of the project.

Finally, all of these comparisons highlight another issue: What makes Big History distinctive? What is it at root? A methodology? A narrative that incorporates work from the many disciplines it incorporates? Whatever else it involves, Big History is a narrative and necessarily so. General laws and theories are inadequate (incomplete) to the task of explaining the past. Contingent events (not reducible to natural laws and general patterns) play a central role in biological evolution and human history. This includes natural contingencies, such as the mass extinctions 66 million years ago that led to the decline of dinosaurs

30 From world history, see Ross E Dunn et al, eds., The New World History: A Field Guide for Teachers and Researchers (Berkeley: University of California Press, 2016; note also a previous edition in 1999). Some of these issues are addressed for Big History in Richard B. Simon et al, eds., Teaching Big History (Berkeley: University of California Press, 2014). and the emergence of mammals as a dominant class of species. It also includes cultural contingencies, such as the human harnessing of fossil fuels that led to the Anthropocene and to humanity playing a driving force in the planet's evolution. ${ }^{31}$ Narration is essential for explanation of specific occurrences and non-replicable instances of cause and effect, as opposed to recurring types that can be modeled and predicted. These narratives are explanatory, not merely descriptive. Like scientific theories they create intellectual order. Narratives "grasp together" causes and effects and series of events into larger wholes, as in the American Revolution, Industrial Revolution, or Anthropocene. ${ }^{32}$ General laws and narratives explain different kinds of things and neither alone is adequate for Big History. My own view is that Big History does not just involve narrative, and necessarily so, but that it is primarily a narrative. Theoretical categories such as complexity, bottlenecks, and thresholds are cyclical narrative markers, as forms of explanation, more than markers of natural laws. To say this is not to identify a weakness in Big History, but to point to its nature.

Here is where Big History can make significant contributions to the humanities and the sciences:

31 For a practical introduction to this theme, see Esther M. van Dijk and Ulrich Kattmann, "Teaching Evolution with Historical Narratives," Evolution: Education and Outreach 2:3 (2009), 479-489.

32 J. David Velleman, "Narrative Explanation," The Philosophical Review 112:1 (January 2003): 8. A valuable exercise in showing how narratives explain is William Cronon, "A Place for Stories: Nature, History, and Narrative," Journal of American History 78:4 (March 1992), 1347-1376. For a useful introduction to issues related to narrative and explanation, see Geoffrey Roberts, ed., The History and Narrative Reader (New York, Routledge, 2001). A classic essay is Louis O. Mink, "Narrative form as a Cognitive Instrument," in Robert H. Canary and Henry Kozicki, eds., The Writing of History: Literary Form and Historical Understanding (Madison, WI: University of Wisconsin Press, 1978). Finally, note Robert F. Berkhofer, Jr., Beyond the Great Story: History as Text and Discourse (Cambridge, MA: Harvard University Press, 1997). On the Anthropocene, see Kelly Power, "Nature or Culture? The Anthropocene as Social Narrative," Inquiries Journal 9:5 (2017), http://www.inquiriesjournal.com/a?id=1643 
highlighting the role of narrative in science. This role is not simply a matter of telling a story about work done in the sciences; narrative is part of the work of doing science, particularly evolutionary science. One of the boundary issues in Big History has been whether Big History is a "science" or "storytelling," some members of the IBHA noting that storytelling is not respected in their field of study. It is "mere" storytelling, the implication is, as opposed to real explanation, which involves universal laws and prediction of cause and effect. ${ }^{33}$ One of the roles big history can play - along with evolutionary history, deep history, and ecological economics - is to help scientists see the explanatory role of narrative in their work and to make historians more comfortable with the role of science and its theoretical models in their work. ${ }^{34}$

\section{Conclusions}

Is Big History a movement culture? This question can be answered both objectively and prescriptively. In my judgment, empirically, Big History acts like a movement culture. Its synthetic, "modern mythology" impulse has been counter-cultural in an intellectual world dominated by disciplinary specialization, and it is seeking to transform not just the work of scholars but school curricula and popular intellectual culture. But this movement culture quality is in tension with Big Historians trying to fit into the frameworks of normal disciplinary science.

33 On science, narrative, and explanation, see, for example, Richard Johnson Sheehan and Scott Rode, "On Scientific Narrative: Stories of Light by Newton and Einstein," Journal of Business and Technical Communication 13:3 (July 1999): 336-58. They argue "that scientific discourse, like all narratives, describes what happened and what it meant. Indeed, scientific texts are almost always accounts of scientists' experiences in reality" (336).

34 An example is William Reddy, The Navigation of Feeling: A Framework for the History of Emotions (New York: Cambridge University Press, 2001). Reddy weaves together research from psychology, anthropology and cultural history. His work is not big history, despite its methodological diversity and breadth, but it exemplifies how putting the sciences, social sciences, and humanities in conversation can work.
What should Big History be? Big History is most likely to have a significant intellectual impact if it embraces its "big tent" nature as an integrative narrative of universal history and finds equitable, intellectually accountable ways to manage the diverse impulses that its supporters bring to the IBHA. Its intellectual power rests precisely in the way its scope entails worldview questions, brings together academic and non-academic participants, pursues academic and non-academic goals, and puts in conversation modes of explanation from the sciences and humanities. Without the very things that have caused discomfort and tension at its conferences, and lead to creative, invigorating conversations in Origins, Big History is likely to be no more than a small academic voice among many other large-scale approaches to the past, perhaps the smallest among them, as deep history and ecological economics are narrower in their academic scope and fit the disciplinary specialization that characterizes mainstream academic work. That is to say, other "big" approaches to the past are less intellectually unruly and less interesting, precisely because they mostly involve scholars talking to themselves, and a narrow range of scholars at that. Only Big History has the narrative audacity to shape school, college, and university curriculum in a broad way. 